\title{
Non-linearity in equity market timing: Empirical evidence from the UK
}

\author{
${ }^{1}$ Hafezali Iqbal Hussain*, ${ }^{1}$ Meor Azli Ayub and ${ }^{2}$ Zurinahni Zainol \\ ${ }^{1}$ School of Distance Education \\ Universiti Sains Malaysia \\ Penang, Malaysia \\ ${ }^{2}$ School of Computer Sciences \\ Universiti Sains Malaysia \\ Penang, Malaysia \\ * Corresponding author: i.hafezali@yahoo.com. Please note that this paper is part of Hafezali Iqbal Hussain's doctoral \\ dissertation.
}

\begin{abstract}
This paper empirically tests the market timing theory to prove that issuing behavior of managers is non-linear. Consistent with the literature we show that mangers increase use of equity to finance their deficit when equities are overvalued and resort to a higher proportion of debt when equities are undervalued. Our results further suggest that mangers however exhibit a distinctive pattern when timing the market. The increase in reliance on equity to finance their deficit during periods of equity overvaluation is non-linear and only significant when the degree of overvaluation is not excessive. Furthermore, during periods of undervaluation managers resort to higher levels of leverage to finance their deficit only when undervaluation levels are excessive. This has serious implications on the ability of the equity market timing as a stand-alone theory in explaining capital structure decisions and poses some interesting implications on the debt-equity choice question when financing the deficit.
\end{abstract}

Keywords - market timing, equity mispricing, capital sructure, UK firms

\section{INTRODUCTION}

The market timing theory of capital structure posits that managers will attempt to increase equity issues when equities are overvalued and opt for debt issues when equities are undervalued. This is based on the assumption that managers are working on the interest of shareholders where value can be delivered if managers successfully time the equity market and lower overall cost of capital. The empirical literature however has shown mixed results as some studies confirm the theory (e.g. [1] and [2]) while others have found contradictory evidence (e.g. [3]; [4]).

In light of the contention found in the literature, we test the theory and find that firms significantly increase equity issues to fund their deficit when equity is overvalued and opt for relatively higher levels of debt when equity is undervalued. Further dissecting the issuance behavior, which is the main objective of this paper, we find that firms exhibit different timing patterns when reacting to different degrees of overvaluation and undervaluation. To the best of our knowledge we are the first to show that timing behavior of firms are non-linear. We segregate our sample into overvalued versus undervalued and find that mangers in fact behave in a non-linear manner when timing the equity market. The evidence shows that firms increase equity issues to fund their deficit when the level of overvaluation is low. Firms do not increase equity issues when the extent level of overvaluation is high. Contrastingly, we find that firms significantly increase reliance on debt issues to fund the deficit only when undervaluation levels are excessive and not when equities are slightly undervalued.

The paper is structured as follows. We review the relevant literature in the next session. In section III, we describe the data, provide variable definitions, describe how equity mispricing is measured, quantify the basic model used throughout the paper and provide initial univariate analysis. Subsequently in section IV, we empirically test how mispricing affects issuance activities using a multivariate model and then consider the non-linear behavior. Section V concludes.

\section{LITERATURE REVIEW}

This section looks at financing pattern of UK firms and how it is influenced by equity prices. Baker and Wurgler [1] argue that the current capital structure of any firm is the cumulative outcome of managers' historical attempts to time the market. The underlying assumption of this theory would be that mangers are correctly able to identify windows of opportunity to lower cost of capital by altering their financing mix to increase firm value. The authors find support for the market timing explanation of capital structure.

\section{A. Deficit and equity pricces}

Shyam-Sunder and Myers [5] first explore the link between net changes in debt issues and the deficit function. The authors argue that if the pecking order explanation of capital structure holds, they would expect to observe a one-toone relationship. Their results support this view and the deficit coefficient outperforms the target adjustment coefficient in explaining net debt issues as well as change in leverage ratios. 
In a subsequent study, [6] find that net equity issued was able to track the financing deficit more closely implying that debt financing is not the main source of external financing given that the coefficient is far larger than for debt financing. Further contention in the literature is provided by [7] who found that the pecking order coefficient doesn't explain their results as the slope for the pecking order coefficient is insignificant in some years.

Looking at SEOs in the US, [3] found a strong correlation with equity prices. Baker and Wurgler [1] conclude that managers would prefer equity over debt when share valuations are higher. Hirshleifer et al. [8] show that investors do not fully incorporate information into decision making which may lead to equity mispricing and thus negating the rational risk taking explanation of investor behavior. The evidence shows that there are windows of opportunity which managers could exploit to time equity issues. Jenter [9] provides further evidence by showing that managers not only time firm level issues, but these actions are also in line with their own private trade of insider ownership. This indicates that managers genuinely believe equity markets may be mispriced and thus are attempting to time equities. Extending the argument further, [10] show that managers would only be able to time the market if there are significant holdings from institutional investors suggesting that how well markets receive a particular issue is also an important aspect when it comes to timing equity issues.

Several studies however have found contradictory evidence. Alti [11] finds that although managers do time the equity market, the effect is short-lived and firms revert to preissue leverage levels in a couple of years. Flannery and Rangan [12] provide further contention to the market timing explanation of capital structure by showing that half of the changes in capital structure is explained by targeting behavior. The authors find that less than $10 \%$ of changes in capital structure is brought about by the pecking order or market timing considerations. In another study, [3] finds that the negative correlation observed between leverage levels and the market-to-book ratio is explained by growth opportunities rather than market timing attempts. Given the ongoing debate in the literature we empirically test the theory and provide some additional insight to improve our understanding of what drives capital structure decisions of firms in the UK.

\section{B. Non-linearity in issuing behavior}

Given the contention in the literature, our paper argues that the issuing behavior of managers is non-linear. Some indication of this behavior is found in [13] who suggest that issuing behavior as a whole is non-linear by showing that firms adjust faster to target leverage when they are overlevered relative to when they are under-levered. The author further shows that when firms are over (under) levered they adjust faster to target levels when they are in a surplus (deficit). Based on the suggested implications from the findings in the literature, we conjecture that issuing is a function of equity valuation condition on the degree of mispricing to finance their deficit.

\section{DATA AND METHOD}

\section{A. Data description and descriptive statistics}

Initially we include all UK firms available from the Datastream Thomson Reuters database during the period of 1992 - 2011. We do not use pre-1992 data as the data is scarcely available. We select our sample based on whether the data is available as well as measuring equity mispricing as proposed in the above discussion. In order to avoid potential survivorship and selection bias, we include dead firms in the sample. Similar to the literature on capital structure studies in the UK, we exclude financial firms. The variables used in the models are defined as follows. Net debt issues, $(\Delta \mathrm{d})$ is the net change in book debt over total assets. Net equity issues $(\Delta \mathrm{e})$ is the change in book equity less the change in retained earnings divided by total assets. SIZE is the natural logarithm of net sales in millions of 1992 pounds. Asset tangibility, (T), is defined as net plant, property and equipment over total assets, while research and development expenses scaled by total assets (RD) and capital expenditure scaled by total assets (CAPEX) are proxies for growth opportunities. Earnings (EBITDA) are measured as earnings before interest, taxation, depreciation and amortization divided by total assets. In order to control for outliers in our estimates we eliminate observations where book value of debt, net debt issues and net equity issues exceed 100\%. Missing firm-year observations are also excluded from the data set. The final sample comprises of 1,642 firms with 18,062 firm-year observations. Panel A in Table 1 presents the summary statistics of the variables used in the study. Panel B in table 1 shows issuing behavior for firms whose equities are undervalued (IVMV > 1) and firms where equities are overvalued (IVMV $<1$ ). The average net debt issued for undervalued firms is more than double relative to overvalued firms and the difference is significant at $1 \%$. Similarly, the net equity issued for firms with overvalued equities is also significantly larger than firms which are undervalued. Thus, we can infer that equity mispricing does indeed influence how the deficit is financed, lending credence to the market timing theory of capital structure.

\begin{tabular}{|c|c|c|c|}
\hline \multicolumn{4}{|c|}{ Table 1: Descriptive Statistics of Sample } \\
\hline \multicolumn{4}{|c|}{ Panel A } \\
\hline Variable & Mean & Median & Standard Deviation \\
\hline$\Delta \mathrm{d}$ & 0.0120 & 0.0020 & 0.1334 \\
\hline$\Delta \mathrm{e}$ & 0.0380 & 0.0140 & 0.1720 \\
\hline DEF & 0.0500 & 0.0120 & 0.1960 \\
\hline$\Delta$ SIZE & 0.0976 & 0.0575 & 0.4920 \\
\hline$\Delta \mathrm{T}$ & -0.0021 & -0.0007 & 0.0820 \\
\hline$\Delta \mathrm{RD}$ & 0.0002 & 0.0001 & 0.0440 \\
\hline$\triangle \mathrm{CAPEX}$ & -0.0044 & -0.0008 & 0.0620 \\
\hline$\Delta$ EBITDA & -0.0058 & -0.0007 & 0.2727 \\
\hline \multicolumn{4}{|c|}{ Panel B } \\
\hline & $\Delta \mathrm{d}$ & $\Delta \mathrm{e}$ & DEF \\
\hline IVMV $>1$ & 0.0164 & 0.0286 & 0.0487 \\
\hline IVMV $<1$ & 0.0078 & 0.0452 & 0.0530 \\
\hline $\begin{array}{l}\text { t-value } \\
\text { (difference) }\end{array}$ & $2.60 * * *$ & $3.34 * * *$ & $1.99 * *$ \\
\hline
\end{tabular}




\section{B. Measuring the financing deficit}

Similar to the literature (see [15]) we define deficit and expand the basic model used in [5] to include the effect of equity mispricing on financing the deficit. Our estimates regresses net debt issues against the deficit function which is defined as $D E F_{i t}$ for firm $i$ in year $t$ as:

$$
D E F_{i t}=D I V_{i t}+I_{i t}+\Delta W_{i t}-C_{i t} \equiv \Delta d_{i t}+\Delta e_{i t}
$$

where $D I V_{i t}$ is cash dividends, $I_{i t}$ is net investments, $\Delta W_{i t}$ is net working capital, $C_{i t}$ is cash flow after interest and taxes. The deficit function is also the sum of net debt issued and net equity issued given that it takes into account internal financing (as cash flow after interest and taxes is taken off from cash outflows).

\section{Measuring equity mispricing}

Equity valuation is measured using the residual income model as used in similar studies in the literature [15], [16] and [14]. Mispricing is measured as the ratio of intrinsic value (IV) to the current market value (MV) (see [17] for a more detailed review of this method). This is based on the study by [18] who decompose the market-to-book ratio into 2 components: a measure of growth options and a measure of valuation. The authors argue that value-to-market measures mispricing while book-to-value measures growth opportunities.

Thus we calculate intrinsic value based on [15] and [16] where intrinsic value is:

$$
I V_{0}=B E_{0}+\sum_{t=1}^{T}(1+k)^{-t} E E_{0}\left[I_{t}-k\right] \times B E_{t-1}+\frac{(1+k)^{-T}}{k} T V
$$

The terminal value, TV, is calculated as follows:

$$
T V=E E_{i 0}\left[\left(I_{T}-k \times B E_{T-1}\right)+\left(I_{T+1}-k \times B E_{T}\right)\right] / 2
$$

$I V_{0}$ is the intrinsic value of the firm's equity at time $0, B E_{0}$ is the book value of equity at time $0, k$ is the cost of equity, and $E E_{0}\left(I_{i}\right)$ is the expected earnings for period $\mathrm{t}$ at time 0 . Time 0 is defined as the previous fiscal year and $\mathrm{T}$ is set to equal 2 years. Similar to [15] and [16] we use 3 years of future growth earnings. The authors argue that although this might appear to be too short a time period to capture all future growth opportunities of the firm, the residual income model does not capitalize raw earnings but employs abnormal earnings (as in Economic Value Added). Similar to their study, we use a perfect foresight version of residual income model (see [17]). Therefore, we define BE as book value of equity and $\mathrm{I}_{\mathrm{i}}$ as income before extraordinary items. Furthermore, we adopt a similar approach by using ex-post realization of earnings which maximizes the sample size but suffers from several issues, notably the issue of endogeneity. The authors point out that the issue of endogeneity would bias against our study finding evidence of mispricing as debt issues would further reduce future earnings due to interest payment commitments. We use the [19] three factor model to estimate the industry cost of equity capital, k. Our results are robust to using a one factor model to estimate cost of equity. Short term treasure bills are used as a proxy for the risk free rate. We calculate terminal value as the average value of the last 2 years of the finite series and is only restricted to positive values as using negative values would indicate that managers would continuously invest in negative NPV projects. Similar to [15] and [16] we use future realized earnings and assume a perfect and unbiased foresight by managers, we are able to proxy for managers more informed expectations. Given that our aim is to measure the deviation of market prices from fundamental value (intrinsic value), we utilize a ratio of intrinsic value to market value (IVMV) and interact this term with the deficit term in our regressions (see [15]). Our basic model in equation (4) and (5) is based on [15] who expand the initial model as expressed in equation of [5] as follows: ${ }^{1}$

$$
\begin{aligned}
& \Delta d_{i t}=\alpha+\beta_{1} D E F_{i t}+\beta_{2}(I V M V \times D E F)_{i t}+\varepsilon_{i t} \\
& \Delta d_{i t}=\alpha+\beta_{1} D E F_{i t}+\beta_{2}(I V M V \times D E F)_{i t}+\beta_{3} \Delta S I Z E_{i t} \\
& +\beta_{4} \Delta T \times_{i t}+\beta_{5} \Delta R D_{i t}+\beta_{6} \Delta E B I T D A_{i t} \\
& +\beta_{7} \Delta C A P E X_{i t}+\varepsilon_{i t}
\end{aligned}
$$

Based on the findings of [5] and [15], we expect the deficit coefficient to be positive and the interaction term coefficient to be positive and significantly different from zero. If the interaction term's coefficient is not significantly different from zero, equity mispricing (market timing considerations) do not influence firms' issuing behavior. In our study, we assume that the cost of debt remains constant. We further include known determinants of capital structure in equation (5), similar to [5] and [15] as an added measure of robustness and expect a positive coefficient for size as larger firms tend to afford more debt and tangibility as tangible assets serve as collateral to debt. Research and development expenditure and capital expenditure serve as proxies for growth. The correlation for earnings before interest, taxes and depreciation is ambiguous as profitable firms would reduce reliance on external sources of financing but would also want to increase debt issues to reduce the amount of taxes paid as interest expenses are tax deductible.

\section{EMPIRICAL RESULTS}

We report the results for estimating the model as expressed in equation (4) in table $2 .^{2}$ We control for firm fixed effects to remove omitted time invariant firms factors that may lead to spurious correlations between net debt issues and equity price

\footnotetext{
${ }^{1}$ We test for multicollinearity for all our regressions and find that the variance inflation factor (VIF) is less than 10 indicating the absence of multicollinearity problem.

${ }_{2}$ All our regressions control for firm fixed effects, report the coefficients and p-values which are based on standard errors which are clustered by firm and year in order to avoid correlation of observations across time for a given firm and correlation across firms for a given year (see [20]). This is to avoid biased standard errors in our unbalanced panel dataset regressions. Our results are robust to using White standard errors [22] although White standard errors are generally smaller and would yield 'more' significant results i.e. smaller p-values.
} 
as well as to control for firm specific differences which are time invariant such as talented management, economic shocks as well as specific customer characteristics.

\begin{tabular}{|c|c|c|c|}
\hline \multicolumn{4}{|c|}{ Table 2: Equity market timing in the UK } \\
\hline & 1 & 2 & 3 \\
\hline \multirow[t]{2}{*}{ CONSTANT } & -0.0160 & $-0.0331 * *$ & $-0.0314^{* *}$ \\
\hline & $(0.18)$ & $(0.04)$ & $(0.02)$ \\
\hline \multirow[t]{2}{*}{$\mathrm{DEF}$} & $0.4122 * * *$ & $0.2466 * * *$ & $0.2457 * * *$ \\
\hline & $(<0.01)$ & $(<0.01)$ & $(<0.01)$ \\
\hline \multirow[t]{2}{*}{ IVMV x DEF } & - & $0.2026 * * *$ & $0.1987 * * *$ \\
\hline & - & $(<0.01)$ & $(<0.01)$ \\
\hline \multirow[t]{2}{*}{$\Delta \mathrm{SIZE}$} & - & - & $0.0140 * * *$ \\
\hline & - & - & $(<0.01)$ \\
\hline \multirow[t]{2}{*}{$\Delta \mathrm{T}$} & - & - & $0.0945^{* * *}$ \\
\hline & - & - & $(<0.01)$ \\
\hline \multirow[t]{2}{*}{$\Delta \mathrm{RD}$} & - & - & $0.0790 * * *$ \\
\hline & - & - & $(<0.01)$ \\
\hline \multirow[t]{2}{*}{$\triangle$ EBITDA } & - & - & $-0.0117 * * *$ \\
\hline & - & - & $(<0.01)$ \\
\hline \multirow[t]{2}{*}{$\triangle \mathrm{CAPEX}$} & - & - & $0.0390 * * *$ \\
\hline & - & - & $(<0.01)$ \\
\hline $\mathrm{R}^{2}$ & 0.4966 & 0.5872 & 0.5950 \\
\hline Adjusted $\mathrm{R}^{2}$ & 0.4023 & 0.5136 & 0.5243 \\
\hline Wald (p-values) & 0.000 & 0.000 & 0.000 \\
\hline Observations & 18062 & 18062 & 18062 \\
\hline Period & $1992-2011$ & $1992-2011$ & $1992-2011$ \\
\hline
\end{tabular}

The first column reports the regression without the interaction term where the deficit variable has a positive coefficient of 0.4122 indicating that about $41 \%$ of the deficit is financed by debt. Looking at our main objective, the results for the regression in column two report the the interaction term which includes the mispricing measure in order to capture the effect of equity prices on issuing behavior where undervalued firms would have an IVMV of greater than 1 and overvalued firms would have and IVMV of less than 1 . The coefficient of the interaction term is a positive and significant 0.2026 indicating that firms would increase (decrease) debt issues during periods of undervaluation (overvaluation) i.e. when IVMV is less than 1. The effect is also economically significant as the coefficient of the deficit has been reduced. This suggests that market timing has not only a statistically but economically significant effect on explaining debt issues. The adjusted $\mathrm{R}^{2}$ for model 2 is also larger than model 1 indicating that the interaction term increases the power of explanation. In column three we include known determinants of capital structure and find that our results are robust. We further find that firm size, tangibility and the growth proxies (research and development as well as capital expenditure) have positive and significant coefficients. Profitability on the other hand has a negative and significant effect on debt issues.

We further split our sample into firm-years which are undervalued (IVMV > 1) and report results in table 3-1, while firm-years which are overvalued (IVMV $<1$ ) are reported in table 3-2. The first column in table 3-1 shows that the coefficient for the interaction term remains positive and significant as expected.

In the second column we expand the model by adding in the quadratic term in order to test for non-linearity in issuing behavior. The second column shows that the first order term is insignificant and the second order term is significant and positive. The results indicate that firms do not increase reliance on debt to finance their deficit when equities are slightly undervalued and only increase debt issues when the extent of undervaluation of equities are more severe.

\begin{tabular}{|c|c|c|}
\hline \multicolumn{3}{|c|}{ Table 3-1: Non-linearity in equity market timing } \\
\hline \multirow{2}{*}{\multicolumn{3}{|c|}{ Undervalued firms (IVMV > 1) }} \\
\hline & & \\
\hline \multirow[t]{2}{*}{ CONSTANT } & $-0.0182 * *$ & $-0.0180 * *$ \\
\hline & $(0.03)$ & $(0.03)$ \\
\hline \multirow[t]{2}{*}{ DEF } & $0.2874 * * *$ & $0.2766^{* * * *}$ \\
\hline & $(<0.01)$ & $(<0.01)$ \\
\hline \multirow[t]{2}{*}{ IVMV x DEF } & $0.2744 * * *$ & 0.0034 \\
\hline & $(<0.01)$ & $(0.19)$ \\
\hline \multirow[t]{2}{*}{$\mathrm{IVMV}^{2} \mathrm{x}$ DEF } & - & $0.2636^{* * *}$ \\
\hline & - & $(<0.01)$ \\
\hline \multirow[t]{2}{*}{$\Delta$ SIZE } & $0.0133 * * *$ & $0.0136^{* * *}$ \\
\hline & $(<0.01)$ & $(<0.01)$ \\
\hline \multirow[t]{2}{*}{$\Delta \mathrm{T}$} & $0.0980^{* * *}$ & $0.0981 * * *$ \\
\hline & $(<0.01)$ & $(<0.01)$ \\
\hline \multirow[t]{2}{*}{$\Delta \mathrm{RD}$} & $0.0663 * *$ & $0.0650 * *$ \\
\hline & $(0.03)$ & $(0.04)$ \\
\hline \multirow[t]{2}{*}{$\Delta$ EBITDA } & $-0.0124 * *$ & $-0.0123 * *$ \\
\hline & $(0.03)$ & $(0.03)$ \\
\hline \multirow[t]{2}{*}{$\triangle \mathrm{CAPEX}$} & $0.0422 * * *$ & $0.0421 * * *$ \\
\hline & $(<0.01)$ & $(<0.01)$ \\
\hline $\mathrm{R}^{2}$ & 0.6340 & 0.6314 \\
\hline Adjusted $\mathrm{R}^{2}$ & 0.5831 & 0.5790 \\
\hline Wald (p-values) & 0.000 & 0.000 \\
\hline Observations & 8454 & 8454 \\
\hline Period & $1992-2011$ & $1992-2011$ \\
\hline
\end{tabular}

Note: $* * *, * *$ and $*$ indicates significance at $1 \%, 5 \%$ and $10 \%$ respectively.

The results in the first column in table 3-2 shows that the interaction term is also positive and significant as expected. Results in the second column shows that the interaction term for the first order is significant while the interaction that using the quadratic term is insignificant. The results further indicate non-linear behavior and prove that firms only increase reliance on equity issues during periods of slight overvaluation rather than severe levels of overvaluation.

\begin{tabular}{|c|c|c|}
\hline \multicolumn{3}{|c|}{ Table 3-2: Non-linearity in equity market timing } \\
\hline & 1 & 2 \\
\hline \multicolumn{3}{|c|}{ Overvalued firms (IVMV < 1) } \\
\hline \multirow[t]{2}{*}{ CONSTANT } & $-0.0146 * *$ & $-0.0160^{* *}$ \\
\hline & $(0.04)$ & $(0.03)$ \\
\hline \multirow[t]{2}{*}{ DEF } & $0.2130 * * *$ & $0.2099 * * *$ \\
\hline & $(<0.01)$ & $(<0.01)$ \\
\hline \multirow[t]{2}{*}{ IVMV x DEF } & $0.1022 * * *$ & $0.1128^{* * *}$ \\
\hline & $(<0.01)$ & $(<0.01)$ \\
\hline \multirow[t]{2}{*}{$\mathrm{IVMV}^{2} \mathrm{x}$ DEF } & - & 0.0040 \\
\hline & - & $(0.26)$ \\
\hline \multirow[t]{2}{*}{$\Delta$ SIZE } & $0.0151 * * *$ & $0.0149 * * *$ \\
\hline & $(<0.01)$ & $(<0.01)$ \\
\hline \multirow[t]{2}{*}{$\Delta \mathrm{T}$} & $0.0922 * * *$ & $0.0926^{* * *}$ \\
\hline & $(<0.01)$ & $(<0.01)$ \\
\hline \multirow[t]{2}{*}{$\Delta \mathrm{RD}$} & $0.0994 * * *$ & $0.0989 * * *$ \\
\hline & $(<0.01)$ & $(<0.01)$ \\
\hline \multirow[t]{2}{*}{$\Delta$ EBITDA } & $-0.0109 * *$ & $-0.0108^{*}$ \\
\hline & $(0.03)$ & $(0.07)$ \\
\hline \multirow[t]{2}{*}{$\triangle \mathrm{CAPEX}$} & $0.0356 * * *$ & $0.0357 * * *$ \\
\hline & $(<0.01)$ & $(<0.01)$ \\
\hline $\mathrm{R}^{2}$ & 0.6641 & 0.6545 \\
\hline Adjusted $\mathrm{R}^{2}$ & 0.5955 & 0.5879 \\
\hline Wald (p-values) & 0.000 & 0.000 \\
\hline Observations & 8605 & 8605 \\
\hline Period & $1992-2011$ & $1992-2011$ \\
\hline
\end{tabular}




\section{CONSClusion}

This paper provides an empirical test on the equity market timing theory on explaining capital structure decisions using unbalanced UK panel data. Our initial results confirm that equity mispricing plays an important role in issuing patterns. The effect is statistically as well as economically significant. Extending the argument further, we test for non-linearity in timing behavior and show that firms do time the market discriminately. We find that during periods of undervaluation, managers only increase reliance on debt issues to finance the deficit as predicted by the market timing theory if the extent of deviation from fundamental value is large. Contrastingly, we find that managers' only significantly increase reliance on equity when overvaluation levels are low rather than excessive. The implications from the empirical results raise some interesting questions which could provide room for further research on the ability of market timing theory as a plausible explanation to capital structure. We delegate this to future research in examining how the extent of mispricing interacts with several other conditions that may affect capital structure decisions.

\section{ACKNOWLEDGMENT}

We are indebted to Muhammed-Shahid Ebrahim, Richard Fairchild, Vidhan Goyal, Alessandra Guariglia, Abdullah Iqbal, Gulnur Muradoglu, Ozde Oztekin, Andrew Vivian and Richard Warr for their valuable feedback, comments and suggestions. We also thank the seminar participants at the University of Hull, UK and Cass Business School School, City University of London.

\section{REFERENCES}

[1] Baker, M. and Wurgler, J. "Market timing and capital structure", Journal of Finance, Vol. 57, 2002, pp. 1-32.

[2] Doukas, J., Guo, J. and Zhou, B. "Hot' debt markets and capital structure', European Financial Management, Vol.17, 2011, pp. 46-99.

[3] Hovakimian, A. 'Are observed capital structures determined by equity market timing?', Journal of Financial and Quantitative Analysis, Vol. 41, 2006, pp. 221-243

[4] Butler, A., Cornaggia, J., Grullon, G. and Weston, J. 'Corporate financing decisions, managerial market timing and real investment', Journal of Financial Economics, Vol. 101, 2011, pp. 666-683.
[5] Shyam-Sunder, L. and Myers, S. 'Testing static tradeoff against pecking order models of capital structure', Journal of Financial Economics, Vol. 51, 1999, pp. 219-244.

[6] Frank, M. and Goyal, V. 'Testing the pecking order theory of capital structure', Journal of Financial Economics, Vol. 6, 2003, pp. 217-248.

[7] Huang, R. and Ritter, J. 'Testing the theories of capital structure and estimating the speed of adjustment', Journal of Financial and Quantitative Analysis, Vol. 44, 2009, pp. 237-271.

[8] Hirshleifer, D., Hou, K. and Teoh, S. 'The accrual anomaly: risk or mispricing?', Management Science, Vol. 58, 2012, pp. 320-335.

[9] Jenter, D. 'Market timing and managerial portfolio decisions', Journal of Finance, Vol. 60, 2005, pp. 1903-1949.

[10] Alti, A. and Sulaeman, J. 'When do high stock returns trigger equity issues?', Journal of Financial Economics, Vol. 103, 2012, pp. 61-87.

[11] Alti, A. 'How persistent in the impact of market timing on capital structure', Journal of Finance, Vol. 61(4), 2006, pp. 1681-1710.

[12] Flannery, M. and Rangan, K. 'Partial adjustment and target capital structures', Journal of Financial Economics, Vol. 79(3), 2006, pp. 469506.

[13] Byoun, S. 'How and when do firms adjust their capital structure towards targets?', Journal of Finance, Vol. 63, 2008, pp. 3069-3096.

[14] Warr, R., Elliott, W., Koeter-Kant, J. and Öztekin, Ö. 'Equity mispricing and leverage adjustment costs', Journal of Financial and Quantitative Analysis, Vol. 47, 2012, pp. 589-616.

[15] Elliott, W., Koeter-Kant, J. and Warr, R. 'A valuation-based test of market timing', Journal of Corporate Finance, Vol.13(1), 2007, pp. 112-128.

[16] Elliott, W., Koeter-Kant, J. and Warr, R. 'Market timing and the debtequity choice', Journal of Financial Intermediation, Vol.17(2), 2008, pp. 175-197.

[17] D'Mello, R., and Shroff, P. 'Equity undervaluation and decisions related to repurchase tender offers: An empirical investigation." Journal of Finance, 55, 2000, pp. 2399-2425.

[18] Rhodes-Kropf, M., Robinson, D.; and Viswanathan, S. 'Valuation waves and merger activity: The empirical evidence.' Journal of Financial Economics, Vol. 77 (3) 2005, pp. 561-603.

[19] Fama, E., and French, K. 'Industry costs of equity." Journal of Financial Economics, Vol. 43 (2) 1997, pp. 153-193.

[20] Petersen, M. 'Estimating standard errors in finance panel data sets: comparing approaches', Review of Financial Studies, Vol. 22, 2009, pp. 435-480.

[21] White, H.A. 'Heteroskedastic-consistent covariance matrix estimator and a direct test of heteroskedasticity', Econometrica, Vol. 48, 1980, pp. 817-838.

\section{Creative Commons Attribution License 4.0 (Attribution 4.0 International, CC BY 4.0)}

This article is published under the terms of the Creative Commons Attribution License 4.0

https://creativecommons.org/licenses/by/4.0/deed.en US 